\title{
Purification and Characterization of Extracellular Lipase from Staphylococcus epidermidis (MTCG 10656)
}

\author{
Sirisha Edupuganti, Lakshmi Parcha, Lakshmi Narasu Mangamoori* \\ Centre for Biotechnology, Jawaharlal Nehru Technological Univerisity Hyderabad, Hyderabad, Telangana, India.
}

\section{ARTICLE INFO}

Article history:

Received on: 03/08/2016

Revised on: 02/09/2016

Accepted on: 28/09/2016

Available online: $31 / 01 / 2017$

Key words:

Extracellular lipase,

Staphylococcus, purification.

\begin{abstract}
Lipases are hydrolytic enzymes with wide range of industrial applications. In the present study Staphylococcus epidermidis strain L2 with ability to produce extracellular lipase enzyme has been isolated from cloth samples collected from the diary industry. The extracellular lipase enzyme has been purified to homogeneity. The purified enzyme has shown a specific activity of $123.95 \mathrm{U} / \mathrm{mg}$. The molecular weight of the purified lipase enzyme was found to be $28 \mathrm{KDa}$. The $\mathrm{pH}$ and temperature optima of the enzyme were recorded as 7.5 and $40^{\circ} \mathrm{C}$ respectively. The lipase enzyme has shown stability and activity in presence of varying concentrations of emulsifier and different substrates.
\end{abstract}

\section{INTRODUCTION}

Lipids constitute a large part of the earth's biomass and lipolytic enzymes play an important role in their degradation. Traditionally pancreatic lipases have been used for applications such as cheese ripening and flavor enhancement (Mark, 2002). Nonetheless lipase or Triacylglycerol lipase (EC 3.1.1.3) was isolated and purified to homogeneity from wide range of sources (Saxena et al., 2003). In recent years, microbial lipases have gained importance over plant and animal lipases for commercial and industrial applications due to their multifold properties (Akoh et al., 2007; Antczak et al., 2009). Among microbial sources, only a few bacterial lipases were studied and purified (Gupta et al., 2004). The most important among the lipase producing bacteria are Bacillus sp (Lee et al., 2015), Achromobacter sp (Toshifumi et al., 2001), Alcaligenes sp. (Masahiro et al., 2009), Arthrobacter sp.(Chaubey et al., 2006), Pseudomonos sp.(Dong et al., 1999), Staphylococcus sp. (Xie et al., 2012), and Chromobacterium sp. (Petra et al., 2001).

\footnotetext{
* Corresponding Author

Email:mangamoori@gmail.com
}

Most of the bacterial lipases are glycoproteins, but few extracellular bacterial lipases are lipoproteins. Lipases are used in many industries (Berhanu and Amare Gessesse, 2012).

They are used in several industries such as fat oleochemical industry for initiation of hydrolysis and glycoclysis of mixed substrates (Gupta et al. 2003), detergent industry to remove fat stains, food processing and bakery industry for flavor development and to improve quality of food by lipolytic hydrolysis of fats and cream (Sharma et al., 2001; Ghosh et al., 1996; Kirk et al., 2002;), paper making industry to remove hydrophilic compounds from pulp (Gutierrez et al., 2009) and textile industry to increase fabric absorbability (Rita et al., 2008). Lipases are also commercially used in biodegradable polymer production, cosmetics (Taneja et al., 2005), cheese flavoring, tea processing and resolution of the racemic mixtures (Talon et al., 1995; Abraham et al., 2011; Shivika Sharma, 2014).

The industrial market for lipases was reported as 1.5 billion US dollars in 2002 (Alain Houde et al. 2004). In view of increasing demand for lipase enzyme and its potential applications in varied industries, the present study was carried out to isolate and purify a stable, cost effective and extracellular lipase and to evaluate its commercial applications. 


\section{MATERIALS AND METHODS}

\section{Microorganism}

Cloth samples collected from dairy industry (Jyothi Dairy Private Limited, RR district, Hyderabad, India). The cloth samples were soaked in sterile distilled water for $10 \mathrm{~min}$ and the water was squeezed from the cloth. The water samples thus obtained were serially diluted and plated on to tributyrin agar base containing $0.5 \%(\mathrm{w} / \mathrm{v})$ peptone, $0.3 \%(\mathrm{w} / \mathrm{v})$ yeast extract, $1 \%(\mathrm{v} / \mathrm{v})$ Tributyrin and $2 \%$ agar, $\mathrm{pH} 7.0$ by spread plate method. Plates were incubated at $37^{\circ} \mathrm{C}$ for two days. Pure cultures of the isolates were maintained on minimal agar media slants (yeast extract, $\mathrm{NaCl}$, Peptone and 2\% agar, $\mathrm{pH} 7.0$ ) and were subcultured every 15 days.

Lipolytic organisms were screened by qualitative plate assay. The isolates were cultured on Tributyrin agar base plates and incubated at $36^{\circ} \mathrm{C}$ for 2 days and the zone of clearance was observed due to hydrolysis of tributyrin. Based on morphological, physiological and biochemical tests, the isolate was identified as Staphylococcus epidermidis. The culture was sent for further identification to IMTECH, Chandigarh where it was identified and designated as Staphylococcus epidermidis strain L2 (MTCC 10656).

\section{Enzyme Assay}

Enzyme activity of lipase is assayed by alkali titration method using olive oil as substrate (Pinsirodom and Parkin, 2001). Olive oil $(10 \% \mathrm{v} / \mathrm{v})$ was emulsified with gum Arabica $(5 \% \mathrm{~m} / \mathrm{v})$ in $100 \mathrm{mM}$ sodium phosphate buffer $\mathrm{pH}$ 7.2. Enzyme sample of 0.1 $\mathrm{ml}$ was added to $0.9 \mathrm{ml}$ of this emulsion. After incubation for 15 minutes at $37^{\circ} \mathrm{C}$, the reaction was stopped and the fatty acids were extracted by addition of $0.1 \mathrm{ml}$ of an acetone/ethanol solution $(1: 1 \mathrm{v} / \mathrm{v})$. The amount of fatty acids liberated was then titrated with $0.05 \mathrm{M} \mathrm{NaOH}$ until pH10.5 using a phenophathelin indicator. Reaction blank was run in the same way, but by adding the sample after the addition of acetone/ethanol solution. The activity of lipase was calculated using the following formula.

( $\mathrm{M}$ of $\mathrm{NaOH}$ ) ( $\mathrm{vol}$ of $\mathrm{NaOH}$ consumed ) (Reaction time in sec)

(time required to consume $\mathrm{NaOH}$ in $\mathrm{sec}$ )(Vol of enzyme used)

One unit of enzyme activity was defined as the amount of enzyme that will hydrolyze $\mu \mathrm{mol}$ of fatty acid from triglycerides.

\section{Enzyme Preparation}

Tributyrin broth containing $1 \%$ olive oil was inoculated with a $48 \mathrm{~h}$ old culture of Staphylococcus epidermidis strain L2 with $1 \%$ inoculums. The culture was incubated for 48 hours at $37^{\circ} \mathrm{C}, 150 \mathrm{rpm}$. The culture was centrifuged at $10,000 \mathrm{rpm}$ for 10 $\min$ at $4^{\circ} \mathrm{C}$. The supernatant obtained was lyophilized and used as crude enzyme preparation for further purification and analysis.

\section{Protein Estimation}

Lowry method was used for the determination of total protein content of the $48 \mathrm{~h}$ old culture supernatant with bovine serum albumin as standard (Lowry et al., 1951).

\section{Enzyme purification \\ Fractionation by acetone precipitation method}

The $48 \mathrm{~h}$ old culture supernatant was precipitated with cold acetone in saturation ranges of $50 \%$ and $100 \%$. These suspensions were then centrifuged at $12,000 \mathrm{rpm}$ for $30 \mathrm{~min}$ in cooling centrifuge at $4^{\circ} \mathrm{C}$. The pellet obtained was dried completely so as to remove any traces of acetone and it was later dissolved in a minimal volume of $20 \mathrm{mM}$ phosphate buffer $(\mathrm{pH}$ 7.2) and stored. The protein samples were assayed for enzyme activity by the standard assay method.

\section{Ion Exchange Chromatography}

The fraction of protein obtained from acetone precipitation was subjected to ion exchange chromatography (macro High-Q-anion exchanger column, 1x10 cm) for further purification. This column was connected to Biological duo flow (FPLC) system. The column was equilibrated using a flow rate of $(1 \mathrm{ml} / \mathrm{min})$ with equilibration buffer $(20 \mathrm{mM}$ phosphate buffer $\mathrm{pH}$ 7.2). The protein fraction obtained from acetone precipitation was loaded on to the Macro High Q column with a flow rate of (1 $\mathrm{ml} / 1 \mathrm{~min})$. The column was washed with equilibration buffer of three column volumes to elute unbound protein.

The bound protein was eluted at the flow rate of $0.5 \mathrm{ml} / \mathrm{min}$ using a linear continuous gradient of $\mathrm{NaCl}$ in equilibration buffer ranging from 0-500 mM. The fractions of $2 \mathrm{ml}$ volume were collected and screened for lipolytic activity. Lipase fractions containing activity were pooled, concentrated and loaded onto gel filtration matrix.

\section{Gel filtration chromatography}

The active fractions obtained from Ion exchange chromatography were concentrated and loaded onto gel filtration chromatography column connected to FPLC. Sephacryl S-200 matrix was loaded with the concentrated protein sample. Isocratic pattern of elution was ensured with a flow rate of $0.1 . \mathrm{ml} / \mathrm{min}$ using double filtered phosphate buffer ( $\mathrm{pH} 7.2$ ). The samples of $0.5 \mathrm{ml}$ fraction size were collected and their protein concentration was determined by reading the absorbance at $280 \mathrm{~nm}$. Fractions were assayed for lipolytic activity. All the fractions with activity were pooled.

\section{Characterization of Lipase \\ Molecular weight determination: SDS-PAGE analysis}

Molecular weight of the purified protein sample obtained from gel filtration chromatography was determined by carrying out Sodium dodecyl sulphate polyacrylamide gel electrophoresis according to the method of Laemmli (1970) using 12\% cross linked polyacrylamide gel. Electrophoresis was carried out at constant voltage of $300 \mathrm{~V}$ and $40 \mathrm{~mA}$ for $100 \mathrm{~min}$ at room temperature and silver staining was used to visualize protein bands on the gels (Morrissey, 1981). Molecular weight of the lipase was estimated by comparing the relative mobility of proteins with the standard molecular marker. 


\section{Determination of pH optima and stability of enzyme}

Lipase enzyme was assayed at different $\mathrm{pH}$ values to obtain optimum $\mathrm{pH}$ for enzyme. The enzyme activity was measured by standard assay method with $5 \% \mathrm{w} / \mathrm{v}$ gum acacia emulsified olive oil as the substrate in different buffer systems such as citrate buffer $(\mathrm{pH} 3.5-6.5)$, phosphate buffer $(\mathrm{pH} 7.5-8.5)$, glycine- $\mathrm{NaOH}(\mathrm{pH} 9.5)$ and carbonate buffer $(\mathrm{pH} 10.5)$. The reaction mixture was incubated for 15 minutes at $37^{\circ} \mathrm{C}$ with $1 \mathrm{ml}$ of the respective buffer systems as blanks. The activity of the enzyme was measured by following the standard enzyme assay.

\section{Determination of temperature optima and stability of enzyme}

The effect of temperature on the enzyme was studied by conducting the assay at different temperatures including $30^{\circ} \mathrm{C}$, $40^{\circ} \mathrm{C}, 50^{\circ} \mathrm{C}, 60^{\circ} \mathrm{C}, 70^{\circ} \mathrm{C}$ and $80^{\circ} \mathrm{C}$ in phosphate buffer at $\mathrm{pH} 7.2$ for 15 minutes using $0.1 \mathrm{ml}$ of olive oil as substrate to obtain optimum temperature.

\section{Effect of emulsifier on enzyme activity}

Lipase activity was assayed with different emulsions made by using varying percentages of gum acacia such as $3 \%, 5 \%$, $7 \%$ and $9 \%$ in $0.1 \mathrm{ml}$ of olive oil and $0.8 \mathrm{ml}$ of phosphate buffer ( $\mathrm{pH}$ 7.2). To each emulsion, $0.1 \mathrm{ml}$ of crude enzyme was added and the reaction was conducted for 15 minutes at $37^{\circ} \mathrm{C}$ with $0.1 \mathrm{ml}$ of phosphate buffer as blank.

\section{Effect of substrate on enzyme activity}

The effect of substrates was studied by incubating $0.1 \mathrm{ml}$ of lipase enzyme with different substrates such as olive oil, groundnut, coconut oil, sesame oil and sunflower oil each emulsified with $5 \% \mathrm{w} / \mathrm{v}$ gum acacia for $15 \mathrm{~min}$ at $37^{\circ} \mathrm{C}$.

\section{Effect of metal ions on enzyme activity}

The effect of various different metal ions such as $\mathrm{Ca}^{+2}$, $\mathrm{Mg}^{+2}, \mathrm{Mn}^{+2}, \mathrm{Hg}^{+2}, \mathrm{Ni}^{+2}, \mathrm{Fe}^{+2}$, EDTA and SDS was studied by preincubating the lipase enzyme with each metal ion $(5 \mathrm{mM}$ concentration) at $36^{\circ} \mathrm{C}$ for $1 \mathrm{~h}$. The activity of the pre-incubated enzyme was determined by following the standard enzyme assay.

\section{RESULTS AND DISCUSSION}

\section{Microorganism}

Initially screening studies were conducted to isolate lipase producing bacteria from cloth samples. Water squeezed from cloth samples collected from dairy industry, Hyderabad, Telangana, India were serially diluted and plated on to nutrient agar plates at a $\mathrm{pH}$ of 7.3 at $36^{\circ} \mathrm{C}$ for 2 days. In total, 12 isolates were obtained from the cloth samples. The isolates were repeatedly subcultured to obtain pure cultures and were maintained on nutrient agar slants. All the isolates were screened for lipolytic activity by culturing on Tributyrin agar base plates $(\mathrm{pH} 7.0)$ at $36^{\circ} \mathrm{C}$ for 2 days. The zone of clearance formed due to hydrolysis of tributyrin indicated the lipolytic activity. Among the isolates one culture that showed profound lipolytic activity was designated as
LSP-1and was chosen for further studies. Based on morphological, physiological and biochemical tests, the isolate was identified as Staphylococcus epidermidis.

Table 1: Morphological, Physiological and Biochemical Characterization of Staphylococcus epidermis.

\begin{tabular}{|c|c|}
\hline Tests & L-2 \\
\hline \multicolumn{2}{|l|}{ Morphological tests } \\
\hline \multicolumn{2}{|l|}{ Colony morphology } \\
\hline Configuration & Circular \\
\hline Margin & Entire \\
\hline Elevation & convex \\
\hline Surface & Smooth \\
\hline Pigment & Cream \\
\hline Opacity & Opaque \\
\hline Gram's reaction & + \\
\hline Cell shape & Coccus \\
\hline Size $(\mu \mathrm{m})$ & $0.5 \mu$ \\
\hline Arrangement & Bunches \\
\hline Spore(s) & - \\
\hline Motility & - \\
\hline \multicolumn{2}{|l|}{ Physiological tests } \\
\hline \multicolumn{2}{|l|}{ Growth at temperatures } \\
\hline $4^{\circ} \mathrm{C}$ & - \\
\hline $10^{\circ} \mathrm{C}$ & - \\
\hline $25^{\circ} \mathrm{C}$ & + \\
\hline $30^{\circ} \mathrm{C}$ & + \\
\hline $37^{\circ} \mathrm{C}$ & + \\
\hline $42^{\circ} \mathrm{C}$ & + \\
\hline $55^{\circ} \mathrm{C}$ & - \\
\hline \multicolumn{2}{|l|}{ Growth at $\mathrm{pH}$} \\
\hline $\mathrm{pH} 4.0$ & - \\
\hline pH 5.0 & - \\
\hline $\mathrm{pH} 6.0$ & + \\
\hline $\mathrm{pH} 7.0$ & + \\
\hline $\mathrm{pH} 8.0$ & + \\
\hline $\mathrm{pH} 10.0$ & + \\
\hline \multicolumn{2}{|l|}{ Growth on $\mathrm{NaCl}(\%)$} \\
\hline 2.0 & + \\
\hline 4.0 & + \\
\hline 6.0 & + \\
\hline 8.0 & + \\
\hline 10.0 & + \\
\hline Growth under anaerobic condition & + \\
\hline \multicolumn{2}{|l|}{ Biochemical tests } \\
\hline Growth on MacConkey & $+(\mathrm{LF})$ \\
\hline Indole test & - \\
\hline Methyl red test & + \\
\hline Voges Proskauer test & + \\
\hline Citrate utilization & - \\
\hline Casein hydrolysis & - \\
\hline Esculin Hydrolysis & - \\
\hline $\mathrm{H}_{2} \mathrm{~S}$ production & - \\
\hline Gas production from glucose & - \\
\hline Gelatin hydrolysis & - \\
\hline Starch hydrolysis & - \\
\hline Nitrate reduction & + \\
\hline Ornithine decarboxylase & - \\
\hline Lysine decarboxylase & $(+)$ \\
\hline Catalase test & + \\
\hline Oxidase test & - \\
\hline Tween 20 hydrolysis & - \\
\hline Tween 40 hydrolysis & - \\
\hline Tween 60 hydrolysis & - \\
\hline Tween 80 hydrolysis & - \\
\hline Dextrose & + \\
\hline Maltose & + \\
\hline Mannitol & - \\
\hline Sucrose & + \\
\hline
\end{tabular}


The culture was sent for further identification to IMTECH, Chandigarh where it was identified and designated as Staphylococcus epidermidis strain L2 (MTCC 10656) (Table 1). Staphylococcus epidermidis strain L2 (MTCC 10656) was cultured in tributyrin broth (pH 7.0) containing $1 \%$ olive oil at $37^{\circ} \mathrm{C}$ and $150 \mathrm{rpm}$ for 48 hours. The culture was centrifuged at $10,000 \mathrm{rpm}$ for $10 \mathrm{~min}$ at $4^{\circ} \mathrm{C}$ and the culture supernatant was used as the crude enzyme for further studies. Protein concentration of the crude extract was estimated as $11.2 \mathrm{mg} / \mathrm{ml}$ by Lowry et al., 1951 method.

\section{Purification of lipase enzyme}

Lipase enzyme produced by Staphylococcus epidermidis was purified to homogeneity. Purification was carried out in three steps viz., acetone precipitation, Ion exchange chromatography (anion) and gel filtration chromatography. The results obtained from purification studies of lipase enzyme are shown in table 2.
The $48 \mathrm{~h}$ old culture was centrifuged culture supernatant was precipitated with $50 \%$ and 50 to $100 \%$ cold acetone. Maximum enzyme activity was observed in $50 \%$ acetone precipitated sample. Maximum activity of $1345 \mathrm{U} / \mathrm{ml}$ was observed in $50 \%$ acetone fraction.

The protein fraction obtained from $50 \%$ cold acetone precipitation was further purified by Macro High Q anion exchange chromatography (Figure IA). Unbound protein samples have shown lipolytic activity. Maximum enzyme activity of the samples was recorded as $812.7 \mathrm{U} / \mathrm{ml}$ with a specific activity of $94.5 \mathrm{U} / \mathrm{mg}$.

The active fraction obtained from ion exchange chromatography was loaded onto Sephacryl S-200 matrix of gel filtration column (Figure IB). The pooled samples with lipolytic activity have shown a maximum enzyme activity of $562.1 \mathrm{U} / \mathrm{ml}$. Purification process has resulted in the lipase enzyme with a specific activity of 123.95 with a yield of $7.5 \%$.

Table 2: Summary of purification studies on Lipase extracted from Staphylococcus epidermidis (MTCC 10656).

\begin{tabular}{|c|c|c|c|c|c|c|}
\hline Purification Steps & Volume (ml) & $\begin{array}{c}\text { Total protein } \\
\text { (mg) }\end{array}$ & $\begin{array}{c}\text { Total activity } \\
(\mathrm{U} / \mathrm{ml})\end{array}$ & $\begin{array}{c}\text { Specific activity } \\
(\mathrm{U} / \mathrm{mg})\end{array}$ & Yield \% & $\begin{array}{c}\text { Fold } \\
\text { purified }\end{array}$ \\
\hline Crude & 100 & 1120 & 7492 & 6.7 & 100 & 1 \\
\hline Acetone & 10 & 54 & 1345 & 24.9 & 17.9 & 3.72 \\
\hline Ion Exchange Chromatography & 10 & 8.6 & 812.7 & 94.5 & 10.8 & 14.1 \\
\hline Gel Filtration Chromatography & 2 & 4.53 & 562.1 & 123.95 & 7.5 & 18.5 \\
\hline
\end{tabular}

A

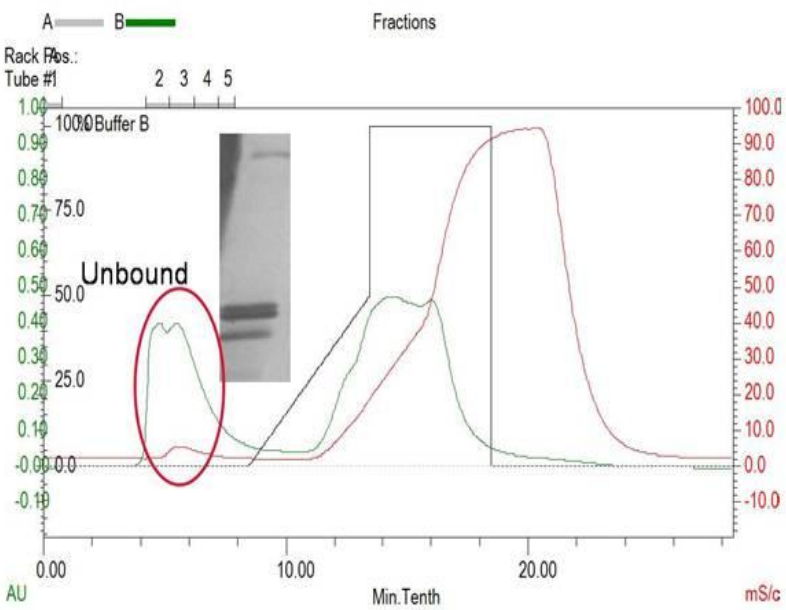

\section{B Chromatogram of Gel filtration Chromatography}

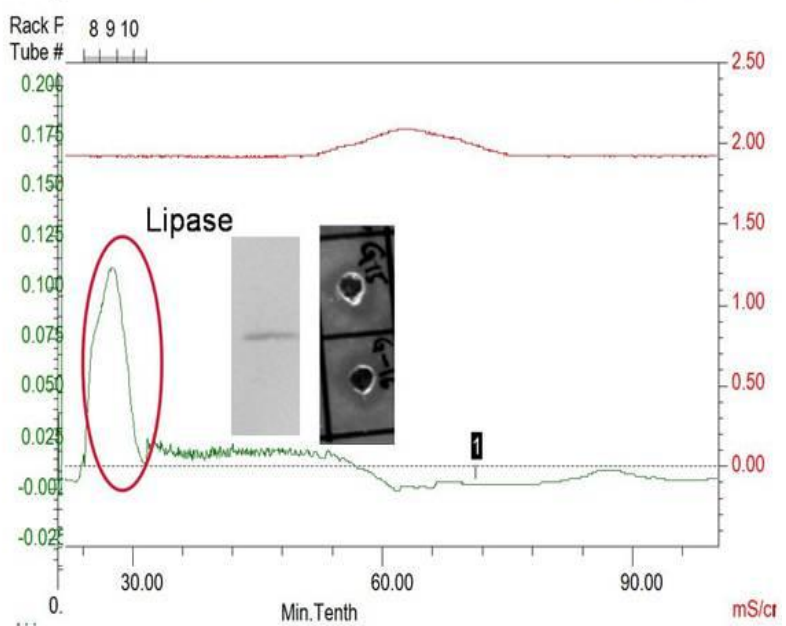

Fig. 1 A \& B: A-Chromatogram of ion exchange chromatography, B-Chromatogram of gel filtration chromatography.

Figure 1 A shows the chromatogram of ion exchange chromatography conducted for the protein fraction obtained from acetone pre cipitation. The enzyme was eluted in unbound fraction. Figure $1 \mathrm{~B}$ shows the chromatogram of gel filtration chromatography of the protein sample obtained from ion exchange chromatography 


\section{Characterization studies}

\section{Determination of molecular weight of purified enzyme}

Molecular weight of the enzyme was determined by SDS PAGE analysis. The gels were stained by using silver nitrate. The purified enzyme showing lipase activity was observed as one single band corresponding to the molecular weight of approximately 28KDa (Figure 2). Lipases (1\&2) purified from, staphylococcus warneri were reported to have molecular weight of 28KDa and 40KDa and those from staphylococcus aureus and S. hyicus have molecular weights ranging from 28 - $46 \mathrm{KDa}$ (Brune A.K.nad Gotz 1992; Valpato et al., 2010).

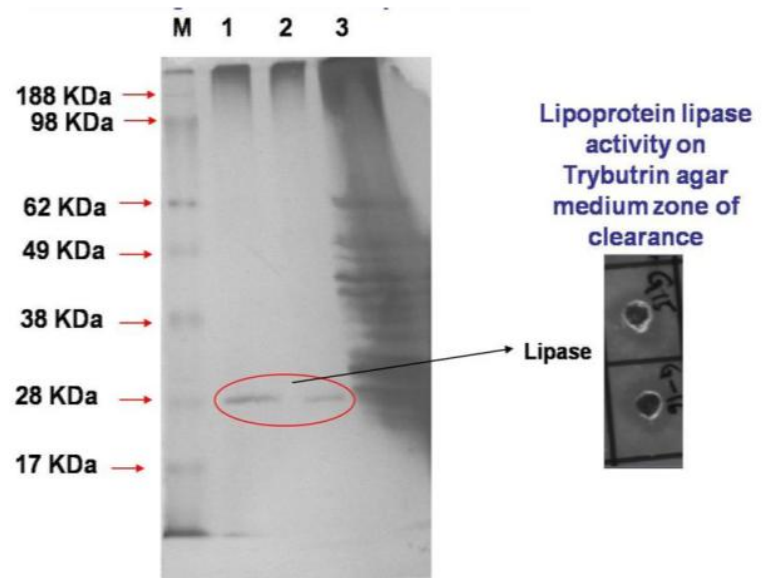

Fig. 2: SDS PAGE analysis of the purified lipase protein. L1 - protein marker, L2- gel filtration sample 1, L3-gel filtration sample 2, L4- crude. SDS PAGE analysis of the protein sample obtained from gel filtration chromatography has shown that the active fraction coincides with the $28 \mathrm{KDa}$ band of standard molecular marker.

\section{Optimum pH and Stability}

The purified enzyme was found to be stable and active over broad $\mathrm{pH}$ range of 4.5 to 9.5 . Maximum activity of the enzyme was observed at $\mathrm{pH} 7.5$ (Figure 3).

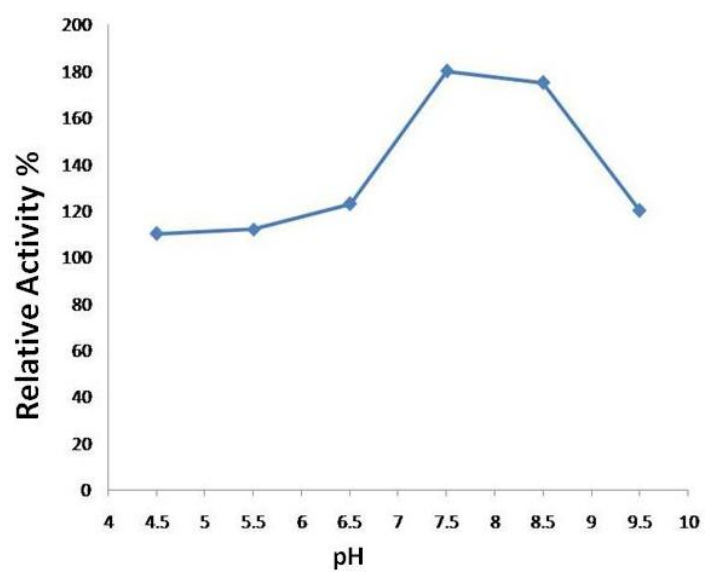

Fig. 3: Effect of $\mathrm{pH}$ over the lipase enzyme from Staphylococcus epidermidis L2. Studies on the effect of $\mathrm{pH}$ over the lipase enzyme activity have indicated that the enzyme is active over a broad range of $\mathrm{pH}$ of $4.5-10.0$ with an optimum $\mathrm{pH}$ of 7.5

A gradual increase in lipase activity was observed from 5.5 to 7.7. Most of the bacterial lipases were reported to be active at neutral $\mathrm{pH}$ and were found to be stable over a broad $\mathrm{pH}$ range of 4 to 11 (Dharmsthiti et al. 1998; Dong et al. 1999). The optimum $\mathrm{pH}$ values of lipases obtained from Staphylococcus aureus and Staphylococcus epidermidis were reported as 8 and 8.5 respectively (Troller and Bozeman, 1970; Xie et al., 2012).

\section{Optimum temperature and Stability}

The lipase enzyme has shown activity over a temperature range of 35 to $45^{\circ} \mathrm{C}$. The maximum enzyme activity was observed at $40^{\circ} \mathrm{C}$ (figure 4 ) and thereafter a sharp decrease in activity was observed up to $60^{\circ} \mathrm{C}$. Temperature range for most of the bacterial lipases was reported as $30-60^{\circ} \mathrm{C}$ (Dharmsthiti and Luchai 1999; Sunna et al., 2002). Temperature optima for lipase produced by staphylococcus species was reported as $32^{\circ} \mathrm{C}$ by Xie et al., in 2012.

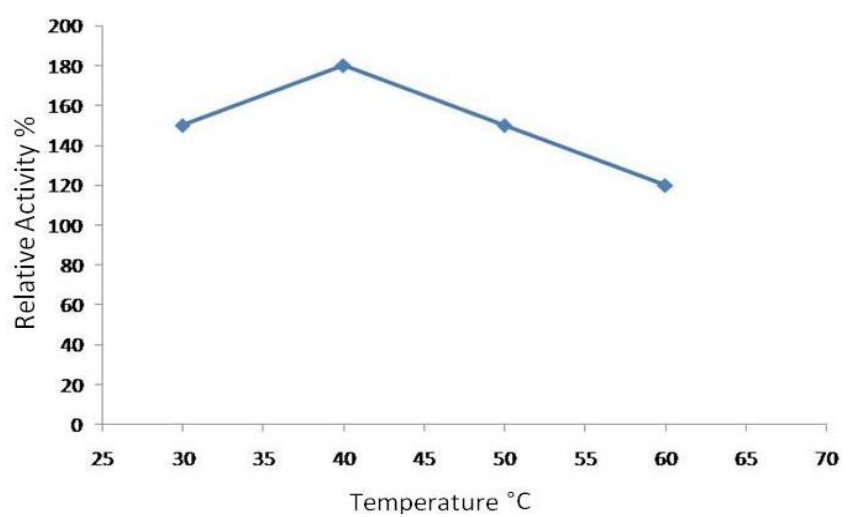

Fig. 4: Effect of temperature over the lipase enzyme from Staphylococcus epidermidis L2. Studies on the effect of temperature over the lipase activity have indicated that the optimum temperature for the maximum enzyme activity is $40^{\circ} \mathrm{C}$.

\section{Effect of emulsifier (Gum Acacia) on the enzyme activity}

Gum Acacia was reported to affect the interfacial binding capacity and activity of the lipase enzyme (Tissa et al., 2001). Concentration of emulsifier was found to directly affect the activity of the enzyme. In the present study, different percentages of the emulsifier (Gum Acacia) were used to obtain the optimum concentration of gum acacia for maximum lipase activity.

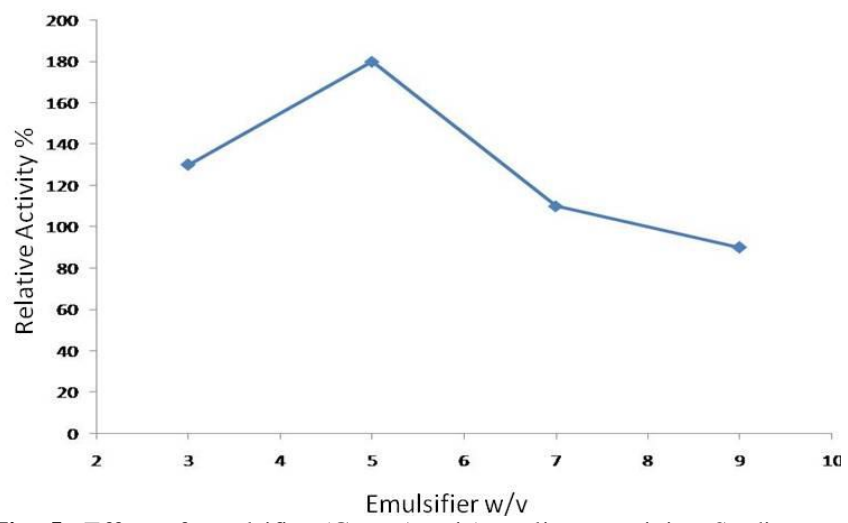

Fig. 5: Effect of emulsifier (Gum Acacia) on lipase activity. Studies on the effect of emulsifier over the lipase enzyme activity have indicated 5\% gum acacia as the optimal emulsifier percentage for enzyme activity 
Enzyme was stable at a range of emulsifier concentrations of 3-9\% however maximum lipase activity was observed with $5 \%$ concentration of Gum acacia (figure 5).

\section{Effect of substrates on enzyme activity}

Bacterial lipases are 1,3-regiospecific. They hydrolyze only primary ester bonds and convert triglycerides to free fatty acids (Gupta et al., 2004). Ground nut oil, sunflower oil, sesame oil and olive oil were used in $10 \%$ concentrations in the present study. Maximum enzyme activity was observed in olive oil and sesame oil whereas in coconut oil enzyme activity was profoundly decreased (figure 6).

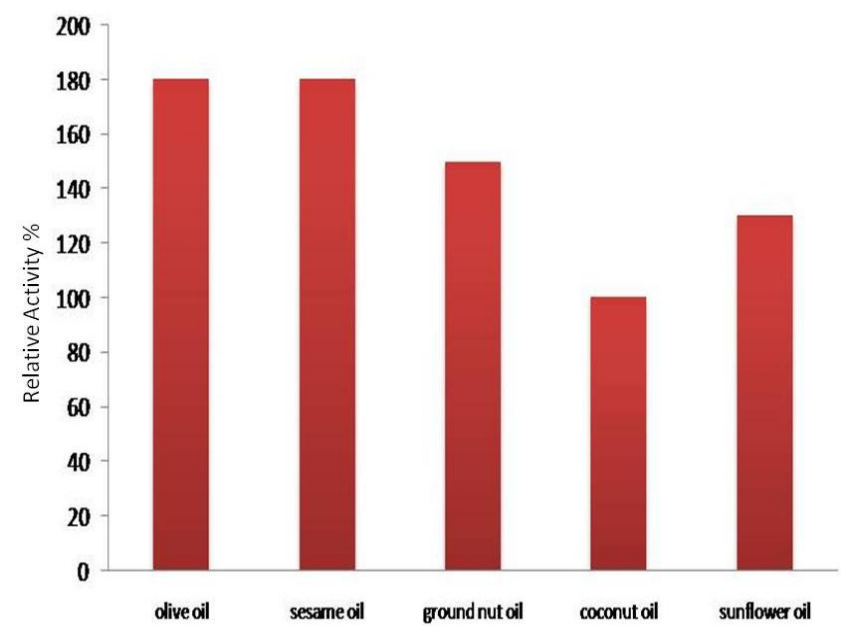

Fig. 6: Effect of different substrates on enzyme activity. Studies on the effect of substrates over enzyme activity have indicated olive oil and sesame oil as the best substrates.

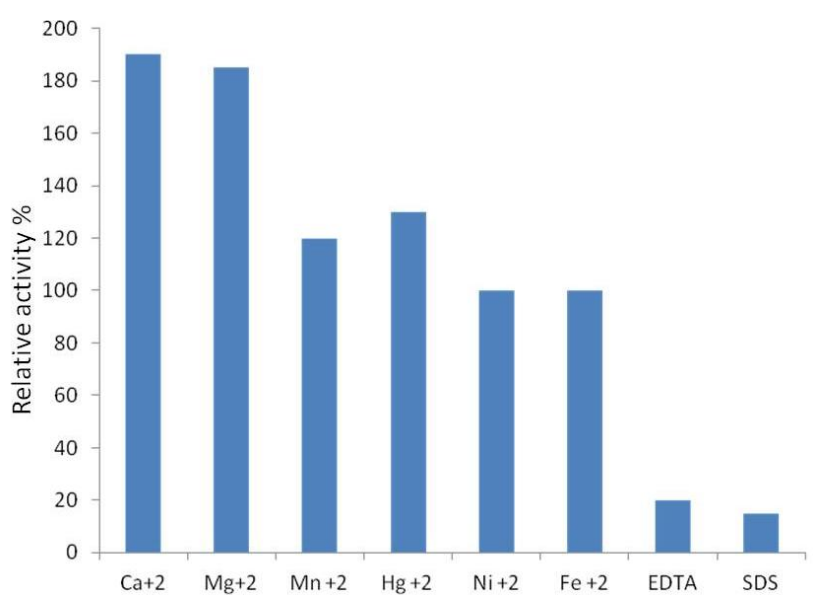

Fig. 7: Effects of metal ions on the lipase activity. Studies on the effect of different metal ions over enzyme activity have indicated $\mathrm{Ca}^{+2}$ and $\mathrm{Mg}^{+2}$ as the enhancers of enzyme activity

\section{Effect of metal ions on enzyme activity}

Maximum enzyme activity was found in presence of $\mathrm{Ca}^{+2}, \mathrm{Mg}^{+2}$. The presence of EDTA and SDS have inhibited $90 \%$ of the lipase activity. Only $50 \%$ of the activity was observed in presence of $\mathrm{Mn}^{+2}, \mathrm{Hg}^{+2}, \mathrm{Ni}^{+2}, \mathrm{Fe}^{+2}$ (figure 7). Lipase isolated from Burkholderia sp. was reported to be stimulated in presence of $\mathrm{Ca}^{+2}$ and $\mathrm{Mg}^{+} 2$ (Rathi et al., 2001).

\section{CONCLUSION}

Lipase is one of the most potential industrial enzymes. In the present study, an extracellular lipase enzyme was isolated from Staphylococcus epidermidis with a molecular weight of $28 \mathrm{KDa}$. The enzyme was found to be stable at $40^{\circ} \mathrm{C}, \mathrm{pH} 7.5$ and in different vegetable oils. This enzyme can be further scale-up for different commercial applications.

\section{Financial support and sponsorship: Nil.}

Conflict of Interests: There are no conflicts of interest.

\section{REFERENCES}

Abraham S, Kamini NR, Gowthaman MK. Process strategies for alkaline lipase production using Aspergillus Niger MTCC 2594, J Appl Pharma. 2011;1(3).2011.

Akoh CC, Chang SW, Lee GC, Shaw JF. Enzymatic approach to biodiesel production, J. Agric. Food Chem. 2007; 55: 8995-9005.

Alain Houde, Ali Kademi, Danielle Leblanc. Lipases and their industrial applications, Appl Biochem Biotechnol. 2004; 118(1):155-170.

Antczak MS, Kubiak A, Antczak T, Bielecki S. Enzymatic biodiesel synthesis-key factors affecting efficiency of the process, Renew. Energy. 2009; 34:1185-1194.

Berhanu Andualema, Amare Gessesse. Microbial Lipases and Their Industrial Applications: Review, Biotechnol, 2012; 11:100-118
Brune
AK,
Gotz
F.

In Microbial Degradation of Natural Products (ed. Winkelmann, G.), VCH, Weinheim. 1992; 243-263.

Chaubey A, Parshad R, Koul S, Taneja SC, Qazi GN. Arthrobacter sp. lipase immobilization for improvement in stability and enantioselectivity, Appl Microbiol Biotechnol. 2006; 73(3):598-606.

Dharmsthiti S, Kuhasuntisuk B. Lipase from Pseudomonas aeruginosa LP602: biochemical properties and application for wastewater treatment, J Ind Microbiol Biotechnol. 1998; 21:75-80

Dharmsthiti S, Luchai S. Production, purification and characterization of thermophilic lipase from Bacillus sp.THL027, FEMS Microbiol Lett. 1999; 179:241-246

Dong H, Gao S, Han S, Cao S. Purification and characterization of a Pseudomonas sp. lipase and its properties in nonaqueous media, Appl Microbiol Biotechnol. 1999; 30:251-256

Ghosh PK, Saxena RK, Gupta R, Yadav RP, Davidson S. Microbial lipases: Production and applications, Sci Prog.1996; 79:119-157

Gupta R, Gupta N, Rathi P. Bacterial lipases: an overview of production, purification and biochemical properties, Appl Microbiol Biotechnol. 2004; 64: 763-781 DOI 10.1007/s00253-004-1568-8

Gupta R, Rathi P, Bradoo S. Lipase mediated upgradation of dietary fats and oils, Crit Rev Food Sci Nutr. 2003; 43:635-644.

Gutierrez A, Del Río JC, Martínez AT. Microbial and enzymatic control of pitch in the pulp and paper industry, Appl Microbiol Biotechnol. 2009; 82( 6): 1005-1018.

Kirk O, Borchert TV, Furlerng CC. Industrial enzyme applications, Curr Opin Biotechnol. 2002; 13: 345-351.

Laemmli UK. Cleavage of structural proteins during assembly of head of bacteriophage T4, Nature. 1970; 227:680-685

$\mathrm{Li} \quad \mathrm{Pin}$ Lee, Hudzaifah Mohamed Karbul, Marimuthu Citartan, Subash CB. Gopinath,Thangavel Lakshmipriya, Thean-Hock Tang. Lipase-Secreting Bacillus Species in an Oil-Contaminated Habitat: Promising Strains to Alleviate Oil Pollution, BioMed Res Intl. 2015; 2015: 9 http://dx.doi.org/10.1155/2015/820575

Lowry OH, Rosebrough NJ, Farr AL, Randall RJ. Protein measurement with the Folin phenol reagent, J Biol Chem. 1951; 193(1):265-275

Mark E. Lowe. The triglyceride lipases of the pancreas, J Lipid Res. 2002; 43:2007-2016 
Masahiro Mori, Ehsan Ali, Dongning Du, Enoch Y. Park. Characterization and optimization of extracellular alkaline lipase production by Alcaligenes sp. using stearic acid as carbon source, Biotechnol Bioprocess Eng. 2009; 14(2):193-201

Morrissey JH. Silver stain for proteins in polyacrylamide gels: a modified procedure with enhanced uniform sensitivity, Anal Biochem. 1981; 117(2):307-310.

Petra C. Traub, Claudia Schmidt-Dannert, Jutta Schmitt , Rolf D. Schmid. Gene synthesis, expression in E. coli, and in vitro refolding of Pseudomonas sp. KWI 56 and Chromobacterium viscosumlipases and their chaperones Appl Microbiol Biotechnol. 2001; 55(2):198-204

Pinsirodom P, Parkin KL. 2001. Lipase Assays. Curr. Protoc. Food Analyt. Chem. C:C3:C3.1.

Rathi P, Saxena RK, Gupta R. A novel alkaline lipase from Burkholderia cepacia for detergent formulation, Process Biochem. 2001; 37:187-192

Rita Araujo, Margarida Casal, Artur Cavaco-Paulo. Application of enzymes for textile fibres processing, Biocatal Biotransform. 2008; 26(5): 332349

Saxena RK, Sheoran A, Giri B, Davidson WS. Purification strategies for microbial lipases, J. Microbiol Methods. 2003; 52:1-18.

Sharma R, Chisti Y, Banerjee UC. Production, purification, characterization and applications of lipases, Biotechnol Adv. 2001; 19:627-662.

Shivika Sharma, Shamsher S. Kanwar. Organic Solvent Tolerant Lipases and Applications Sci World J.2014; Article ID 625258, 15 pages. http://dx.doi.org/10.1155/2014/625258

Sunna A, Hunter L, Hutton CA, Bergquist PL. Biochemical characterization of a recombinant thermoalkalophilic lipase and assessment of its substrate enantioselectivity, Enzyme Microb Technol. $2002 ; 31: 472-476$

Talon R, Dublet N, Montel MC, and Cantonnet M. Purification and characterization of extracellular Staphylococcus warneri lipase, Curr Microbiol. 1995; 30(1):11-16.
Taneja SC, Sethi VK, Andotra SS, Koul S, Qazi GN. Rose oxides: a facile chemo and chemo-enzymatic approach, Synth. Commun. 2005; 35(17): 2297-2303.

Tiss A, Carriere F, Verger R. Effects of gum arabic on lipase interfacial binding and activity, Anal Biochem. 2001;294(1):36-43.

Toshifumi Miyazawa, Tomoyuki Yukawa, Takashi Koshiba, Shinichi Ueji, Ryoji Yanagihara, Takashi Yamada. Enzymatic resolution of 2-phenoxy-1-propanols through the enantioselective acylation mediated by Achromobacter sp. Lipase, Biotechnol Lett. 2001; 23(19):1547-1550

Troller JA and Bozeman MA. Isolation and Characterization of a Staphylococcal Lipase, Appl Microbiol. 1970; 20(3): 480-484

Volpato G, Filice M, Ayub MA, Guisan JM, Palomo JM. Single-step purification of different lipases from Staphylococcus warneri, J Chromatogr A. 2010; 1217(4):473-478.

Xie W, Khosasih V, Suwanto A, Kim HK. Characterization of lipases from Staphylococcus aureus and Staphylococcus epidermidis isolated from human facial sebaceous skin, J Microbiol Biotechnol. 2012; 22(1):84-91

\section{How to cite this article:}

Edupuganti S, Parcha L, Mangamoori LN. Purification and Characterization of Extracellular Lipase from Staphylococcus epidermidis (MTCC 10656). J App Pharm Sci, 2017; 7 (01): 057063. 